\title{
REDUCTION OF pH BY HOMOLACTIC FERMENTATION AS INDICATOR OF FECAL COLIFORM INACTIVATION IN WASTEWATER
}

\section{REDUCCIÓN DEL pH POR FERMENTACIÓN HOMOLÁCTICA COMO INDICADOR DE LA INACTIVACIÓN DE COLIFORMES FECALES EN AGUA RESIDUAL}

\author{
Jean Poll Alva-Araujo1, Gustavo A. Cano-Arcos², Juan G. Juscamaita-Morales ${ }^{3}$ \\ and Lawrence Quipuzco Ushñahua ${ }^{4}$
}

\begin{abstract}
The purpose of this research was to evaluate the capability of lactic acid bacteria (LAB) to remove pathogens present in domestic wastewater, generated in the eco-touristic circuit Lomas de Lucumo (Lima, Peru). The $\mathrm{pH}$ decrease was used as an indicator of the elimination of fecal coliform bacteria in the treated water. Experiments included 36 treatments, which consisted of different mixtures of sugar molasses and a lactic acid bacteria inoculum (B-Lac) in proportions of $0,1,3,5$, 7 and $10 \%(\mathrm{v} / \mathrm{v})$ and wastewater in a fixed proportion of $200 \mathrm{ml}$, under a completely randomized design (CRD) with factorial arrangement $6 \times 6$. The $\mathrm{pH}$ values on the third day were evaluated using an Analysis of Variance (ANOVA) followed by Tukey's range test for mean differences $(\mathrm{p}<0.05)$. The different treatments were analyzed in a first stage for 9 days, after which the best three were selected for a second evaluation: T16 (3\% molasses and 5\% B-Lac), T22 (5\% molasses and 5\% BLac) and T33 (10\% molasses and 3\% B-Lac); results show that the interaction effect between the two variables is significant. Finally, treatment T16 was selected as the most efficient, reaching a pH of 4.08 in a short time (3 days) that assured the complete removal of fecal coliform bacteria $\left(9.65 \times 10^{5} \mathrm{MPN} / 100 \mathrm{ml}\right)$ in the wastewater.
\end{abstract}

Key words: wastewater, treatments, lactic acid, pathogen, fecal coliform.

\section{Resumen}

El objetivo de esta investigación fue evaluar la capacidad de las bacterias del ácido láctico (BAL) para eliminar los patógenos presentes en el agua residual doméstica, generada en el circuito ecoturístico Lomas de Lúcumo (Lima, Perú). La disminución del pH se usó como un indicador de la eliminación de bacterias coliformes fecales en el agua tratada. Los experimentos incluyeron 36 tratamientos que consistieron en diferentes mezclas de melaza de azúcar y un inóculo de bacterias ácido lácticas (B-Lac) en proporciones de 0, 1, 3, 5, 7 y 10\% (v/v) y agua residual en una proporción fija de $200 \mathrm{ml}$, bajo un diseño completamente al azar (CRD) con arreglo factorial 6x6. Los valores de $\mathrm{pH}$ en el tercer día se evaluaron utilizando un Análisis de varianza (ANOVA) seguido de la prueba de Tukey para la diferencia de medias $(\mathrm{p}<0.05)$. Los diferentes tratamientos se analizaron en una primera etapa durante 9 días, seleccionando los tres mejores para una segunda evaluación: T16 (3\% de melaza y 5\% de B-Lac), T22 (5\% de melaza y 5\% de B-Lac) y T33 (10\% de melaza y $3 \%$ de B-Lac); los resultados muestran que el efecto de interacción entre las dos variables es significativo. Finalmente, el tratamiento T16 fue seleccionado como el más eficiente, alcanzando un pH de 4.08 en un corto período de tiempo (3 días), que aseguró la eliminación completa de bacterias coliformes fecales $\left(9.65 \times 10^{5} \mathrm{MPN} / 100 \mathrm{ml}\right)$ en el agua residual.

Palabras clave: agua residual, tratamientos, ácido láctico, patógeno, coliformes fecales.

\section{Introduction}

In the last decade, there has been a growing worldwide concern related to water quality issues (Orta, 2002). In developing countries, there is a real struggle for access to water due to the rapid demographic growth, new life habits, and industrial development without proper planning (Delgadillo et $a l ., 2010)$. Mainly, inappropriate wastewater disposal, garbage, mining tailings, and chemical products have caused water pollution (Chulluncuy, 2011). The first has its most important source in homes and industries, as the wastewater is sent directly to the sewage system where different qualities of wastewater mix and ultimately reach a natural water body without the necessary treatment (Lahera, 2010).

Treating wastewater and reusing it for non-potable applications poses a potential solution for areas with limited access to water which are common around the globe (Winward et al., 2008). Typical uses for the treated wastewater revolve around agricultural, industrial, recreational and aquifer recharge activities (Guadarrama \& Galván, 2015). In many Latin American countries, wastewater is commonly used without a previous treatment or diluted with natural water bodies, which causes health problems, especially when the untreated water is used for irrigation in fields 
destined for direct human consumption (Silva et al., 2008). This type of usage represents a risk, as wastewater is a source of pathogens such as bacteria, viruses, protozoa and worms, which cause gastrointestinal infections in humans (Veliz et al., 2009).

In this stage, finding new technological alternatives for wastewater treatment that are of low cost and simple requirements of operation and maintenance is a necessity (Delgadillo et al., 2010). Despite the development of multiple treatment technologies including centralized and decentralized systems, in general, the treatment capacity is relatively low in developing countries due to economic limitations (Wu et al., 2016). As the need for big-scale treatment systems grows fast, effort must be put into developing alternatives that are economically accessible and efficient.

Efficient microorganisms have been successfully applied in many aspects of environmental management (Okuda \& Higa, 1999). These organisms mostly have fermentative properties, can produce bioactive substances, compete and display antagonism with pathogens, which can have positive impacts on both human health and the ecosystem (Romero \& Vargas, 2017). Their potential for water treatment relies on their capability to enhance the natural process of oxidation (Higa \& Chinen, 1998). The efficient microorganisms are leaded by lactic acid bacteria (LAB) which secrete organic acids that create acidic conditions down to a $\mathrm{pH}$ of 4.7 (Axelsson, 2004, citado por León et al., 2006). This $\mathrm{pH}$ drop is considered as the main inhibiting agent of growth for pathogenic microorganisms (Carrasco et al., 2002). Most lactic acid bacteria have a high tolerance to $\mathrm{pH}$ below 5 (Serna \& Rodriguez, 2005), which gives them a competitive advantage over other bacteria (Hofvendahl \& Hahn, 2000). The acidic conditions can lead to the removal of fecal coliform in wastewater, which needs the $\mathrm{pH}$ to be between 5.5 and 7.5 to survive (McFeters \& Stuart, 1972).

One common application of lactic acid bacteria is as bio-preservative because of the production of substances with antibacterial properties, which prevent the decomposition of food products and the development of pathogenic microorganisms (Martín del Campo et al., 2008). Another biotechnological application of lactic acid bacteria is the production of liquid organic fertilizer. With this, Peralta et al. (2016) transformed the excreta of cattle into liquid organic fertilizer with good characteristics in a short time. Furthermore, Mindreau et al. (2016) evaluated physicochemical and microbiological parameters in a process of human feces stabilization through the inoculation of lactic acid bacteria from a solution called Biolac (or B-lac), accomplishing the stabilization of the residue in only 3 days. In addition, the application of LAC in water treatment has been investigated by Corpas \& Herrera (2012), who obtained a reduction in coliform bacteria (41.1\%) and Escherichia coli (48\%) in effluents from a milk production plant, using efficient microorganisms.

The purpose of this study is to evaluate the effect of lactic acid bacteria, in the form of a lactic acid microbial consortium (B-lac), on the $\mathrm{pH}$ decrease to remove fecal coliform in domestic wastewater from the eco-touristic circuit Lomas de Lucumo, located in the Rural Village Center Quebrada Verde, in Pachacámac, (Lima, Peru). Experiments were conducted in the Environmental Biotechnology and Bioremediation Laboratory (Department of Biology) at the National Agrarian University La Molina (UNALM). This research aims to establish a biotechnological method for the fast and economic elimination of pathogens in domestic wastewater with the purpose of its later use in irrigation.

\section{Materials and methods}

Wastewater characterization

The wastewater was characterized for the main water quality parameters as shown in Table 1 . The values were determined in the Environmental Biotechnology and Bioremediation Laboratory and the Environmental Engineering Laboratory, both at UNALM.

Table 1. Average values of the physical, chemical, and microbiological parameters analyzed in the wastewater - Lomas de Lucumo.

\begin{tabular}{lll}
\hline Parameter & Unit & $\begin{array}{l}\text { Concentration in } \\
\text { wastewater - } \\
\text { Lomas de } \\
\text { Lucumo }\end{array}$ \\
\hline $\begin{array}{l}\text { Temperature } \\
\text { Electric }\end{array}$ & ${ }^{\circ} \mathrm{C}$ & 25.6 \\
conductivity & $\mathrm{uS} / \mathrm{cm}$ & 1244 \\
$\mathrm{pH}$ & & \\
Total suspended & $\mathrm{mg} / \mathrm{l}$ & 8.11 \\
solids & & 16.67 \\
BOD & $\mathrm{mg} / \mathrm{l}$ & 13.24 \\
COD & $\mathrm{mg} / \mathrm{l}$ & 25.33 \\
Fecal coliforms & $\mathrm{MPN} / 100 \mathrm{ml}$ & $9.65 \times 10^{5}$ \\
\hline
\end{tabular}

MPN: most probable number. BOD: biological oxygen demand. COD: chemical oxygen demand.

\section{Microbiological analysis of B-lac}

The lactic acid microbial consortium, or B-lac, was characterized for key microbiological parameters in the Marino Tabusso Laboratory, at UNALM (Table 2). The aim was to determine if there is a presence of pathogens that would contaminate the sample or others that could interfere in the process of lactic acid fermentation. The microbiological analysis was carried out according to the procedures described by the Salfinger \& Tortorello (2015).

Sampling and conditioning

Wastewater sampling was done on two occasions. The first consisted of the sampling of 10 , taken from 
the wastewater storage box from the sanitary facilities in the eco-touristic circuit (used for the first stage of experiments and the wastewater characterization). In the second, only 51 of wastewater were sampled which were used to evaluate the three best treatments determined in the first stage of the experiments. Samples were transported to the Environmental Biotechnology and Bioremediation Laboratory at UNALM, where they were stored at $4{ }^{\circ} \mathrm{C}$ until used for the experiments.

Table 2. Microbiological analysis of B-lac.

\begin{tabular}{lll}
\hline Microorganism & Unit & Result \\
\hline Viable Aerobic Mesophilic Bacteria & CFU/ml & $42 \times 10$ \\
Molds and yeasts & CFU/ml & $70 x 10$ \\
Total Coliforms & MPN/ml & $<3$ \\
Fecal Coliforms & MPN/ml & $<3$ \\
\hline
\end{tabular}

Note: Values $<3$ indicate the absence of microorganisms. MPN: most probable number. CFU: colony-forming unit.

\section{Experimental design and preparation of treatments}

Two factors were established: the percentage $(\%)$ by volume of molasses and the percentage (\%) by volume of the B-Lac solution, each in 6 levels. These were evaluated in a Completely Randomized Design (CRD) in a 6x6 factorial arrangement with three repetitions. 36 treatments were prepared in triplicate using combinations of 6 concentrations of B-Lac and 6 of molasses in proportions of $0(0 \mathrm{ml}), 1(2 \mathrm{ml}), 3(6$ $\mathrm{ml}), 5(10 \mathrm{ml}), 7(14 \mathrm{ml})$, and $10 \%(20 \mathrm{ml})$, as shown in Table 3 . These percentages were measured in respect of a wastewater volume of $200 \mathrm{ml}$ (fixed volume) used for each treatment. The labeled containers were hermetically sealed to provide anaerobic conditions and were exposed to environmental conditions in the laboratory (average temperature of $34^{\circ} \mathrm{C}$ ).

For treatments, a lactic acid bacterial consortium (B-Lac) composed of the genus Lactobacillus, Streptococcus, and Bifidobacterium, which was prepared in the Environmental Biotechnology and Bioremediation Laboratory, was used. In addition, sugar cane molasses was the main source of soluble carbohydrates, nutrients, and growth factor (Peralta $e t$ al., 2016), which was obtained from the stable at UNALM.

The variation of $\mathrm{pH}$ as a function of time was used as the response variable, as shown in Figure 1. The $\mathrm{pH}$ values on the third day of measurements were analyzed with an Analysis of Variance (ANOVA) followed by Tukey's range test, using a level of significance of $95 \%$ $(\mathrm{p}<0.05)$.

Evaluation of $\mathrm{pH}$ variation

The experiments consisted of two stages. First, the $\mathrm{pH}$ values were evaluated in the 36 treatments during 9 days using the potentiometric method according to Londoño et al. (2010). Subsequently, the three best treatments that met the criteria described by Peralta $e t$ al. (2016) were selected; a good treatment has to meet the following: $\mathrm{pH} \leq 4.5$, rapid $\mathrm{pH}$ decrease to around 4, absence of bad odor, and no formation of mold or yeast layers.

The second stage of evaluation aimed to determine the best treatment out of the three selected during the first stage. Three repetitions were considered for each treatment and the decrease in $\mathrm{pH}$ was evaluated during 4 days.

Microbiologic analysis of treated wastewater

After the second stage of evaluation, the best treatment was chosen. The effectiveness of each treatment was evaluated by determining the removal of fecal coliform. The methodology used was the most probable number (MPN), according to the recommendations established in the Standard Methods (APHA, 2017).

Table 3. Composition of the 36 treatments based on molasses, B-lac, and wastewater.

\begin{tabular}{crrr}
\hline T & $\begin{array}{c}\text { B-Lac } \\
\text { (ml) }\end{array}$ & $\begin{array}{c}\text { Molasses } \\
\text { (ml) }\end{array}$ & $\begin{array}{c}\text { Wastewater } \\
\text { (ml) }\end{array}$ \\
\hline T1 & 0 & 0 & 200 \\
T2 & 0 & 2 & 200 \\
T3 & 0 & 6 & 200 \\
T4 & 0 & 10 & 200 \\
T5 & 0 & 14 & 200 \\
T6 & 0 & 20 & 200 \\
T7 & 2 & 0 & 200 \\
T8 & 2 & 2 & 200 \\
T9 & 2 & 6 & 200 \\
T10 & 2 & 10 & 200 \\
T11 & 2 & 14 & 200 \\
T12 & 2 & 20 & 200 \\
T13 & 6 & 0 & 200 \\
T14 & 6 & 2 & 200 \\
T15 & 6 & 6 & 200 \\
T16 & 6 & 10 & 200 \\
T17 & 6 & 14 & 200 \\
T18 & 6 & 20 & 200 \\
T19 & 10 & 0 & 200 \\
T20 & 10 & 2 & 200 \\
T21 & 10 & 6 & 200 \\
T22 & 10 & 10 & 200 \\
T23 & 10 & 14 & 200 \\
T24 & 10 & 20 & 200 \\
T25 & 14 & 0 & 200 \\
T26 & 14 & 2 & 200 \\
T27 & 14 & 6 & 200 \\
T28 & 14 & 10 & 200 \\
T29 & 14 & 14 & 200 \\
T30 & 14 & 20 & 200 \\
T31 & 20 & 0 & 200 \\
T32 & 20 & 2 & 200 \\
T33 & 20 & 6 & 200 \\
T34 & 20 & 10 & 200 \\
T35 & 20 & 14 & 200 \\
T36 & 20 & 20 & 200 \\
\hline T: treatments. & & \\
& & &
\end{tabular}




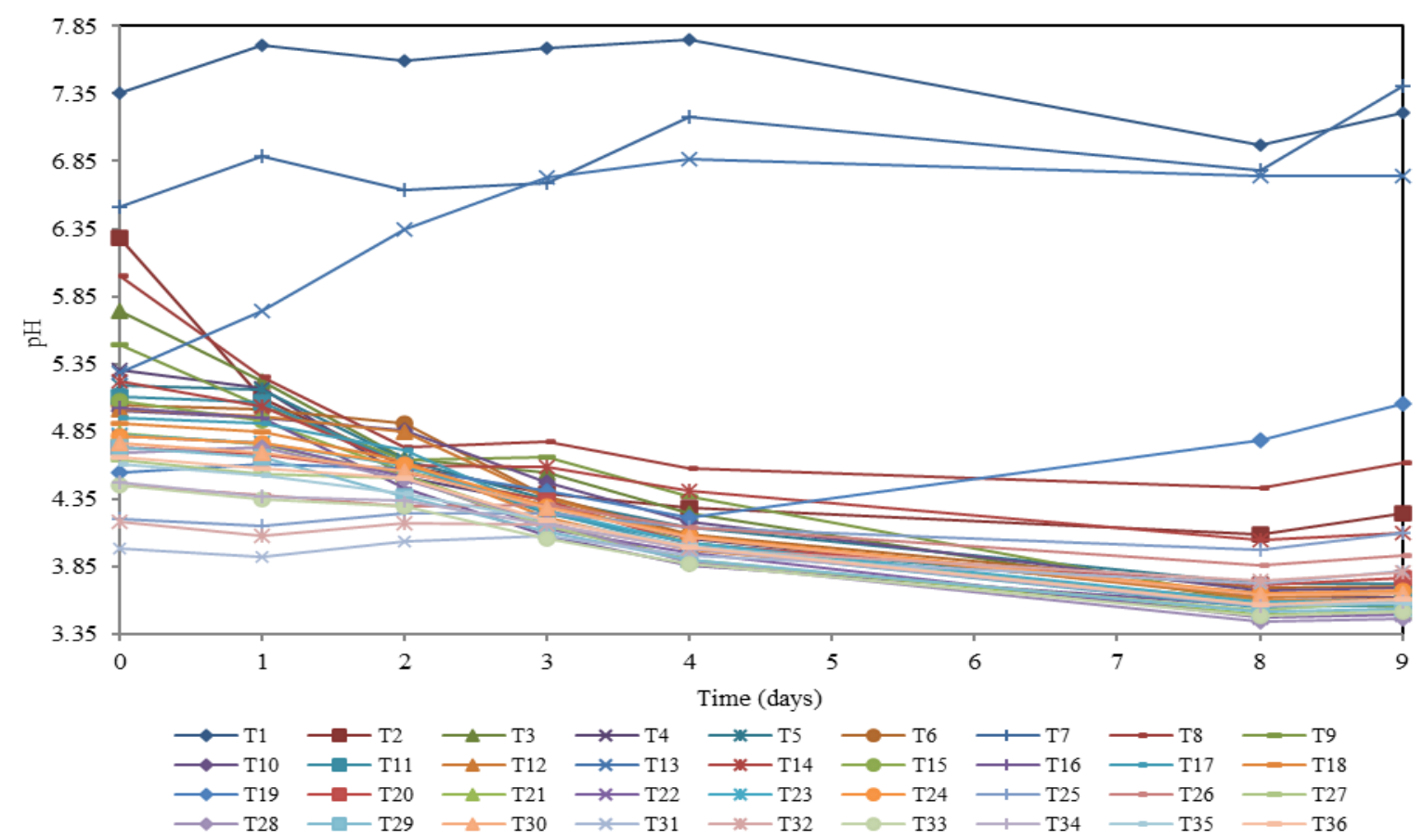

Figure 1. Variation of $\mathrm{pH}$ in the 36 treatments as a time function (first stage).

\section{Results and discussion}

\section{First stage of evaluation of 36 treatments}

Before preparing the treatments, the initial $\mathrm{pH}$ of the wastewater was 8.11 , while the molasses had a $\mathrm{pH}$ of 5.05 and the B-Lac solution registered a value of 3.86 . Due to this, when preparing the 36 treatments, most of them stabilized at a low $\mathrm{pH}$ after 3 minutes. In addition, the average temperature at which the fermentation process was evaluated was $33^{\circ} \mathrm{C}$. According to Delgadillo et al. (2010), this value is within the optimum range for the development of microorganisms, so the speed at which the $\mathrm{pH}$ decreased in the treatments was favored. The lactic acid microorganisms improve the organoleptic properties of the substrate on which they act (Alejo et al. cited by Quiñones et al., 2016). For this reason, most of the treatments applied presented a characteristic aroma similar to that of corn liquor as fermentation is the process that drives both the preparation of this drink as well as the experiments itself.

Figure 1 shows the behavior of the $\mathrm{pH}$ in each of the 36 treatments during the first evaluation stage (9 days). This graph serves as a general overview of the $\mathrm{pH}$ trends and helps to identify the treatments with desirable behavior. It is observed that most of the treatments start with a $\mathrm{pH}$ in the range of [4 - 7.8]; from day 8 the $\mathrm{pH}$ remained constant in most of the treatments, except for T1, T7, T13, and T19. In these, no molasses was added, which is the main carbon source for lactic acid bacteria, providing them with energy to efficiently perform their fermenting activity. A high volume of B-Lac without molasses causes a process of starvation, which leads to the consumption of the nutrients contained in the B-Lac itself. The opposite effect is observed in treatments with high concentrations of molasses, where the bacteria reach the stationary phase faster, before consuming the entire substrate, which induces a stoppage in the production of biomass, due to the saturation state of the substrate compared to the concentration of microorganisms (Ossa et al., 2010). Another effect that was detected in the treatments that do not have a source of molasses (T1, T7, T13, and T19) is that the $\mathrm{pH}$ increases showing chaotic tendencies. This $\mathrm{pH}$ increase causes a decrease in the growth of bacteria in a culture medium (Ortiz et al., 2008). A trend of fast $\mathrm{pH}$ decrease to a value close to 4 is distinguished in most of the treatments; this $\mathrm{pH}$ decrease was slower after the fourth day of evaluation.

Due to the large number of treatments that were shown in Figure 1, only those that met the criteria described by Peralta et al. (2016) were analyzed in detail in Figure 2. Therefore, 10 treatments that showed an accelerated $\mathrm{pH}$ decrease were selected, reaching values below 4.5 (in the range of $4.0-4.2$ ) on the third day, absence of bad odor, and no formation of mold or yeast layers. Moreover, treatments that reached low $\mathrm{pH}$ values on the third day but did not show a significant variation were discarded (T31 and T32).

Figure 2 presents three bars (black, gray, and dark gray) for each treatment, which represent the $\mathrm{pH}$ reached on days 0,3 , and 4 . Also, an orange bar is shown for each treatment, which indicates the variation of $\mathrm{pH}$ (delta) between day 3 (D3) and day 0 (D0) of evaluation (absolute value). The analysis of Figure 2 
aims to select the best treatments for the second stage of evaluation. Thus, on day 3 it is observed that two treatments have the lowest $\mathrm{pH}$ values: T16 (4.08) and T33 (4.06), which were selected for the second stage of evaluation. Besides, two other treatments with low $\mathrm{pH}$ values were found on the third day: T22 (4.13) and T29 (4.11). However, only T22 was selected because its composition has a lower requirement of molasses (10 $\mathrm{ml})$ compared to that of T29 $(14 \mathrm{ml})$. This criterion is based on favoring lower-cost options for water treatment since greater quantities of molasses will translate into a higher cost of the process, especially if we aim to provide a big-scale and low-cost viable treatment option.

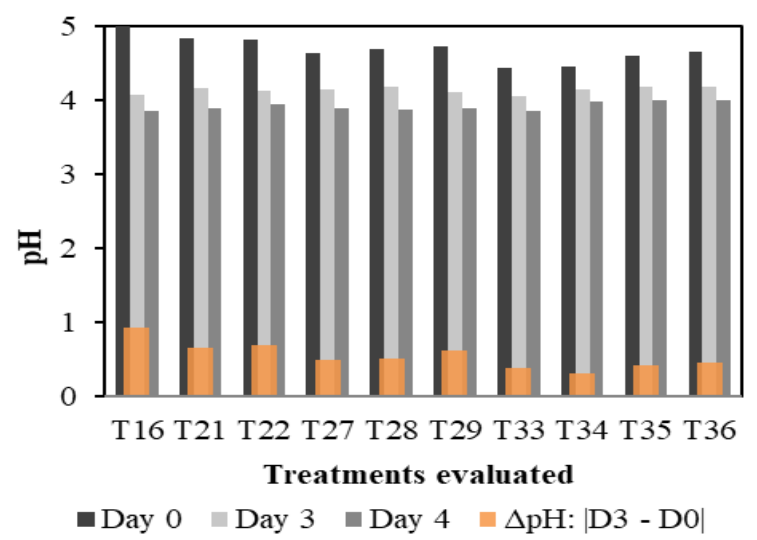

Figure 2. Treatments that reached $\mathrm{pH}$ values between $4-4.5$ on the third day and showed significant $\mathrm{pH}$ variation during the first stage.

The $\mathrm{pH}$ decrease is attributed to the homofermentative metabolism possessed by lactic acid bacteria, in which mainly lactic acid is produced (Serna \& Rodriguez, 2005). When lactic acid bacteria generate this acid, the $\mathrm{pH}$ of the fermented material drops to a level that inhibits the presence of putrefying bacteria (Garcés et al., 2004). This is expressed in the decrease of $\mathrm{pH}$, an indicator that guarantees the absence of unwanted pathogens (Carrasco et al., 2002). It is relevant to mention that heterofermentative bacteria may have also been present in the mix, as they could have been living in the wastewater or the molasses; however, it is safe to assume that the medium was dominated by homofermentative bacteria as the inoculum (B-lac) was prepared to contain exclusively this type of lactic acid bacteria and there were no signs of significant gas formation, which is a clear indicator of the heterofermentative metabolism.

Second stage of evaluation of the 3 best treatments

The second stage of experiments consisted of the evaluation of $\mathrm{pH}$ decrease applying treatments $\mathrm{T} 16$, T22, and T33 (in triplicate) during 4 days. Figure 3 shows that $\mathrm{T} 33$ has a slower $\mathrm{pH}$ decrease compared to that of T22 and T16 between the first and second day, therefore it is discarded. Between T16 and T22 no significant differences were noted in their fermenting activity, which leads to an analysis of the composition of each treatment. Both had the same quantity of molasses $(10 \mathrm{ml})$, but T16 had a lower amount of BLac solution $(6 \mathrm{ml})$ compared to $\mathrm{T} 22(10 \mathrm{ml})$, which is why T16 was chosen as the best treatment since it is preferable that the food source (molasses) exists in greater proportion than lactic acid bacteria to avoid problems of scarcity.

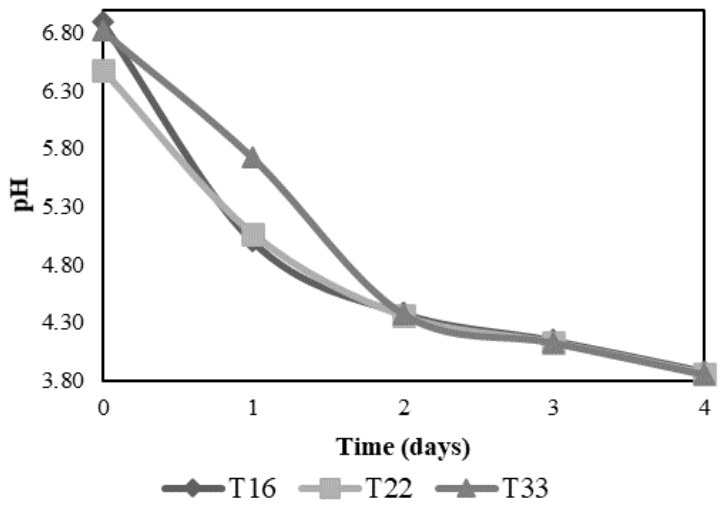

Figure 3. Variation of $\mathrm{pH}$ in the three best treatments (Second stage).

Microbiologic evaluation of the three best treatments

After 3 days of fermentation, the pathogen removal efficiency of T16 was evaluated by the most probable number method (MPN) to determine the presence of fecal coliform. This group of bacteria is used as a general indicator of water quality (García \& Iannacone, 2014). Table 4 shows the removal of the fecal coliform bacteria in treatment T16. The enhancement of the coliform removal in T16 occurs because the efficient microorganisms inoculum have high populations of lactic acid bacteria (Lactobacillus and Pedicoccus), which produce lactic acid and other antimicrobial products as a consequence of the metabolism of carbohydrates (Tannock, 2004). One of the characteristics of this treatment is that it had enough substrate, which prevents the competition for nutrients amongst lactic acid bacteria and other present microorganisms. Corpas \& Herrera (2012) observed that competition during the activation of their microbial mix, coupled with other factors, hindered its ability to deploy its arsenal for the inhibition of coliform populations. As shown in Table 2, the microbiological analysis of the B-Lac solution used indicates an absence of fecal and total coliforms (MPN.ml-1 $<3$ ), from which one can infer that the complete inactivation of the fecal coliforms in the wastewater treated with T16 was caused by the fermenting activity of Lactobacillus sp. in the lactic acid microbial consortium, which is the predominant microorganism present. Another characteristic that would have favored the antagonistic behavior against lactic acid pathogens 
was the production of antimicrobial peptides and low molecular weight compounds such as bacteriocin class I (Kelly, 1998).

Table 4. Result of microbiological analysis of initial wastewater and waste treated with the T16.

\begin{tabular}{|c|c|c|c|}
\hline $\begin{array}{c}\text { Microbiological } \\
\text { parameter }\end{array}$ & Unit & $\begin{array}{c}\text { Wastew } \\
\text { ater }\end{array}$ & $\begin{array}{c}\text { Water } \\
\text { treated } \\
\text { with } \\
\text { T16* }\end{array}$ \\
\hline Fecal coliforms & $\mathrm{MPN} / 100 \mathrm{ml}$ & $9.65 \times 10^{5}$ & $<3$ \\
\hline
\end{tabular}

Interaction of the B-lac and the molasses

Figure 4 presents the interaction effects of the B-lac (B0 to B10) and the molasses (M0 to M10) on the $\mathrm{pH}$ values on the third day of evaluation. This graph suggests that an interaction effect between the two factors studied exists, as the behavior of the $\mathrm{pH}$ cannot be explained by each variable alone. The ANOVA confirmed that there is a significant effect of the interaction, as well as that coming from the different molasses and B-lac concentrations (Table 5); the effect of the molasses levels seems to be the strongest. It is to note that although some treatments with a level of $0 \%$ of molasses or B-lac reach a $\mathrm{pH}$ of around 4.0 on the third day, they are significantly different from the mean of the other levels for each factor, as shown in Table 6 and Table 7. This supports the decision to discard such treatments. As for the three selected treatments (T16, $\mathrm{T} 22$, and T33), the $\mathrm{pH}$ values on the third day do not show a significant difference between them, according to Tukey's test $(\mathrm{p}<0.05)$.

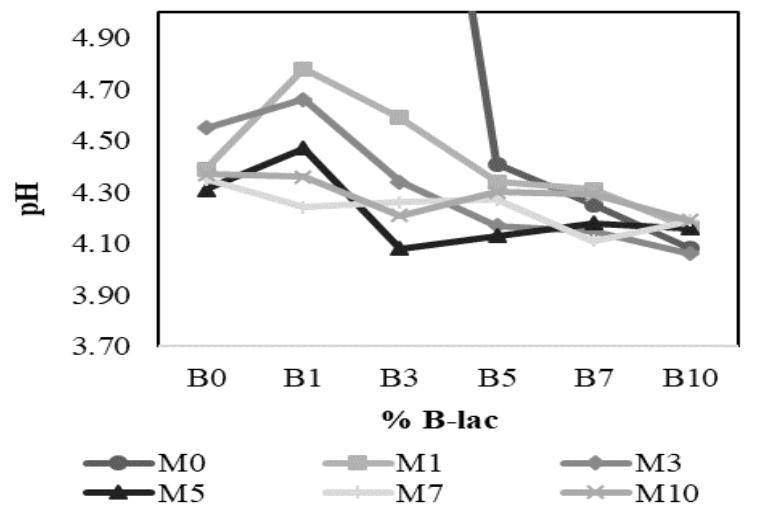

Figure 4. Interaction of molasses (M) and B-lac (B) concentrations on $\mathrm{pH}$ on the third day of evaluation.

\section{Conclusions}

This study showed that wastewater treatments with lactic acid bacteria tend to reach a stable $\mathrm{pH}$ from the fourth day on, generally achieving values below 5.0, which favor the inactivation of pathogenic microorganisms. The short periods in which the optimum $\mathrm{pH}$ values are achieved are a desirable characteristic as it shortens the total treatment length, which represents a reduction in costs.

In conclusion, the best result for the complete elimination of fecal coliforms in the wastewater samples from the sanitary facilities in the eco-touristic circuit Lomas de Lucumo was obtained with treatment T16. This treatment consisted of $6 \mathrm{ml}$ of B-Lac and $10 \mathrm{ml}$ of molasses to treat $200 \mathrm{ml}$ of water in a period of 3 days; results show that the effect of the interaction between molasses a B-lac exists and is significant. The selected treatment reached a $\mathrm{pH}$ of 4.08 in the first evaluation stage and 4.15 in the second stage, achieving a $100 \%$ removal efficiency of fecal coliform bacteria in a narrow time frame. T16 could serve as an alternative remediation/treatment process for domestic wastewater since it supposes a low (but effective) cost of inputs due to the moderate use of the carbon source for the bacteria (molasses). However, to implement this system at a pilot scale, it is suggested that future studies carry out a comprehensive evaluation of the B-Lac efficiency to remove parameters such as Biological Oxygen Demand (BOD) and Chemical Oxygen Demand (COD).

\section{Acknowledgements}

We want to thank B. Sc. Eng. Ivan Alberto Rodríguez Pulache for the support in data analysis for this article and Mr. Alfredo Castillo, resident of the Rural Village Center Quebrada Verde, for granting us access to take samples from the sanitary facilities in Lomas de Lucumo. We also want to show gratitude to Dr. María de Los Angeles García-Hernández for her great support in the revision of the present article.

\section{Cited literature}

APHA (American Public Health Association), AWWA (American Water Works Association) \& WEF (Water Environment Federation). 2017. 9221 Multiple-Tube Fermentation Technique for Members of the Coliform Group. Standard Methods for the Examination of Water and Wastewater. DOI: 10.2105/SMWW.2882.192.

Carrasco M.S., Scarinci H.E. \& Simonetta A.C. 2002. Antibacterial activity of lactic acid bacteria isolated from Argentina dairy products. Australian Journal of Dairy Technology, 57(1): 15-19. https://diaa.asn.au/publications/australian-journal-ofdairy-technology/search-full-issues?page $=14$.

Chulluncuy N. 2011. Tratamiento de agua para consumo humano. Ingeniería Industrial, 29: 153-170. DOI: http://dx.doi.org/10.26439/ing.ind2011.n029.232.

Corpas E. \& Herrera O. 2012. Reducción de coliformes y Escherichia coli en un sistema residual lácteo mediante microorganismos benéficos. Biotecnología en el Sector Agropecuario y Agroindustrial, 10(1): 67-76. https://revistas.unicauca.edu.co/index.php/biotecnologia/ article/view/793.

Delgadillo O., Camacho A., Pérez L. \& Andrade M. 2010. Depuración de aguas residuales por medio de humedales artificiales. Centro Andino para la Gestión y Uso del Agua (Centro AGUA) / Universidad Mayor de San Simón. Editor Antequera N. Cochabamba / Bolivia. https://core.ac.uk/download/pdf/48017573.pdf. 
Garcés A., Berrio L., Ruiz S., Serna J. \& Builes A. 2004. Ensilaje como fuente de alimentación para el ganado. Revista Lasallista de Investigación, 1(1): 66-71. http://hdl.handle.net/10567/179.

García L. \& Iannacone J. 2014. Pseudomonas aeruginosa un indicador complementario de la calidad de agua potable: Análisis bibliográfico a nivel de Sudamérica. The Biologist (Lima), 12 (1): 133-152. https://sisbib.unmsm.edu.pe/BVRevistas/biologist/v12_n 1/pdf/rev2v12n1.pdf.

Guadarrama E. \& Galván A. 2015. Impacto del uso de agua residual en la agricultura. Revista Iberoamericana de las Ciencias Biológicas y Agropecuarias, 4(7): 22-44. http://www.ciba.org.mx/index.php/CIBA/article/view/29.

Higa T. \& Chinen N. 1998. EM Treatments of Odor, Waste Water, and Environment Problems. College of Agriculture, University of the Ryukyus, Okinawa, Japan.

Hofvendahl K. \& Hahn-Hägerdal B. 2000. Factors affecting the fermentative lactic acid production from renewable resources. Enzyme and Microbial Technology, 26(2-4): 87-107. DOI: https://doi.org/10.1016/s0141-0229(99)00155-6.

Kelly W., Davey G. \& Ward L. 1998. Characterization of lactococci isolated from minimally processed fresh fruit and vegetables. International Journal of Food Microbiology, 45(2): 85-92.

DOI: 10.1016/s0168-1605(98)00135-4.

Lahera V. 2010. Infraestructura sustentable: las plantas de tratamiento de aguas residuales. Quivera, 12(2): 58-69. https://quivera.uaemex.mx/article/view/10189.

León Á., Montoya O., Motato K., Granda D., Caro C., Restrepo J., Echeverri S., Valencia J. \& Quinchía L. 2006. Bacterias ácido lácticas (bal) silvestres colombianas presentan propiedades adecuadas para la fabricación de masa ácida. Vitae, Revista de la Facultad de Química Farmacéutica, 13(2): 26-35. http://www.scielo.org.co/pdf/vitae/v13n2/v13n2a04.pdf.

Londoño A., Giraldo G. \& Gutiérrez Á. 2010. Métodos analíticos para la evaluación de la calidad fisicoquímica del agua. Universidad Nacional de Colombia sede Manizales. Editorial Blanecolor Ltda. Caldas, Colombia.

Martín del Campo C., Gómez H. \& Alaníz R. 2008. Bacterias ácido lácticas con capacidad antagónica y actividad bacteriocinogénica aisladas de quesos frescos. e-Gnosis, 6: Art 5. http://www.e-gnosis.udg.mx/index.php/egnosis/article/view/83.

McFeters G. \& Stuart D. 1972. Survival of coliform bacteria in natural waters: field and laboratory studies with membrane-filter chambers. Applied Microbiology, 24(5): 805-811. https://aem.asm.org/content/24/5/805.

Mindreau E., Juscamaita J. \& Williams M. 2016. Estabilización de heces humanas provenientes de baños secos por un proceso de fermentación ácido láctica. Ecología aplicada, 15(2): 143-150. DOI: dx.doi.org/10.21704/rea.v15i2.754.

Okuda A. \& Higa T. 1999. Purification of Waste Water with Effective Microorganisms and its Utilization in Agriculture. Proceedings of the 5th International Conference on Kyusei Nature Farming. Senanayake YDA and Sangakkara UR. (Ed) APNAN, 23-26 October 1977, Bangkok, Thailand. 246-253. http://www.infrc.or.jp/knf/5th_Conf_S_8_2.html.
Orta L. 2002. Contaminación de las aguas por plaguicidas químicos. Fitosanidad, 6(3): 55-62.

http://www.fitosanidad.cu/index.php/fitosanidad/article/ view/840.

Ortiz A., Reuto J., Fajardo E., Sarmiento S., Aguirre A., Arbeláez G., Gómez D. \& Quevedo-Hidalgo B. 2008. Evaluación de la capacidad probiótica "in vitro" de una cepa nativa de Saccharomyces cerevisiae. Universitas scientiarum,

13(2): 138-148. https://revistas.javeriana.edu.co/index.php/scientarium/a rticle/view/1418.

Ossa J., Vanegas M. \& Badillo Á. 2010. Evaluación de la melaza de caña como sustrato para el crecimiento de Lactobacillus plantarum. Revista U.D.C.A Actualidad \& Divulgación Científica, 13(1): 97-104. DOI: doi.org/10.31910/rudca.v13.n1.2010.713.

Peralta L., Juscamaita J. \& Meza V. 2016. Obtención y caracterización de abono orgánico líquido a través del tratamiento de excretas del ganado vacuno de un establo lechero usando un consorcio microbiano ácido láctico. Ecología aplicada, 15(1): 1-10. DOI: dx.doi.org/10.21704/rea.v15i1.577.

Quiñones H., Trejo W. \& Juscamaita J. 2016. Evaluación de la calidad de un abono líquido producido vía fermentación homoláctica de heces de alpaca. Ecología aplicada, 15(2): 133-142. DOI: dx.doi.org/10.21704/rea.v15i2.753.

Romero T. \& Vargas D. 2017. Uso de microorganismos eficientes para tratar aguas contaminadas. Ingeniería hidráulica y ambiental, 38(3): 88-100. http://riha.cujae.edu.cu/index.php/riha/article/view/412.

Salfinger Y. \& Tortorello M.L. (Eds). 2015. Compendium of Methods for the Microbiological Examination of Foods. 5th Ed. Chapter 8 and 21. APHA (American Public Health Association). DOI: https://doi.org/10.2105/MBEF.0222.

Serna-Cock L. \& Rodríguez-de Stouvenel A. 2005. Producción biotecnológica de ácido láctico: estado del arte. Ciencia y Tecnología Alimentaria, 5(1): 54-65. DOI: https://doi.org/10.1080/11358120509487672.

Silva J., Torres P. \& Madera C. 2008. Reuso de aguas residuales domésticas en agricultura. Una revisión. Agronomía Colombiana, 26(2): 347-359. https://revistas.unal.edu.co/index.php/agrocol/article/vie w/13521.

Tannock G. 2004. A Special Fondness for Lactobacilli. Applied and environmental microbiology, 70(6): 31893194. DOI: 10.1128/AEM.70.6.3189-3194.2004.

Veliz E., Llanes J., Asela L. \& Bataller M. 2009. Reúso de aguas residuales domésticas para riego agrícola. Valoración crítica. Revista CENIC Ciencias Biológicas, 40(1): $35-44$. https://www.redalyc.org/pdf/1812/181221574007.pdf

Winward G., Avery L., Frazer-Williams R., Pidou M., Jeffrey P., Stephenson T. \& Jefferson B. 2008. A study of the microbial quality of grey water and an evaluation of treatment technologies for reuse. Ecological Engineering, 32(2): 187-197. DOI: doi.org/10.1016/j.ecoleng.2007.11.001.

Wu S., Carvalho Pedro N., Müller Jochen A., Remony V. \& Donga R. 2016. Sanitation in constructed wetlands: A review on the removal of human pathogens and fecal indicators. Science of the Total Environment, 541: 8-22. DOI: doi.org/10.1016/j.scitotenv.2015.09.047. 
Table 5. Analysis of Variance (ANOVA).

\begin{tabular}{lcrlccc}
\hline Origin of variations & SS & df & MS & F cal & p-value & Sig. \\
\hline Molasses & 27.53 & 5 & 5.506 & 20.95 & $7.326 \mathrm{E}-13$ & yes \\
B-lac & 11.38 & 5 & 2.276 & 8.659 & $1.832 \mathrm{E}-06$ & yes \\
Interaction & 27.82 & 25 & 1.113 & 4.234 & $8.241 \mathrm{E}-07$ & yes \\
Error & 18.93 & 72 & 0.263 & & & \\
Total & 85.67 & 107 & 0.801 & & & \\
\hline $\mathrm{p}<0.05$. & & & & &
\end{tabular}

Table 6. Tukey's test for main effects of molasses concentrations.

\begin{tabular}{ccccccc}
\hline \multicolumn{2}{c}{ Levels } & Diff. mean & mean crit. & lower & upper & p-value \\
Group 1 & Group 2 & & & & & \\
\hline $0 \%$ & $1 \%$ & 1.21 & 0.500 & 0.713 & 1.714 & $1.08 \mathrm{E}-05$ \\
$0 \%$ & $3 \%$ & 1.32 & 0.500 & 0.820 & 1.820 & $7.51 \mathrm{E}-07$ \\
$0 \%$ & $5 \%$ & 1.42 & 0.500 & 0.920 & 1.920 & $6.08 \mathrm{E}-08$ \\
$0 \%$ & $7 \%$ & 1.41 & 0.500 & 0.905 & 1.905 & $8.87 \mathrm{E}-08$ \\
$0 \%$ & $10 \%$ & 1.36 & 0.500 & 0.855 & 1.855 & $3.12 \mathrm{E}-07$ \\
$1 \%$ & $3 \%$ & 0.11 & 0.500 & -0.394 & 0.607 & $9.89 \mathrm{E}+02$ \\
$1 \%$ & $5 \%$ & 0.21 & 0.500 & -0.294 & 0.707 & $8.31 \mathrm{E}+02$ \\
$1 \%$ & $7 \%$ & 0.19 & 0.500 & -0.309 & 0.692 & $8.71 \mathrm{E}+02$ \\
$1 \%$ & $10 \%$ & 0.14 & 0.500 & -0.359 & 0.642 & $9.61 \mathrm{E}+02$ \\
$3 \%$ & $5 \%$ & 0.10 & 0.500 & -0.400 & 0.600 & $9.92 \mathrm{E}+02$ \\
$3 \%$ & $7 \%$ & 0.09 & 0.500 & -0.415 & 0.585 & $9.96 \mathrm{E}+02$ \\
$3 \%$ & $10 \%$ & 0.04 & 0.500 & -0.465 & 0.535 & $1.00 \mathrm{E}+03$ \\
$5 \%$ & $7 \%$ & 0.01 & 0.500 & -0.485 & 0.515 & $1.00 \mathrm{E}+03$ \\
$5 \%$ & $10 \%$ & 0.06 & 0.500 & -0.435 & 0.565 & $9.99 \mathrm{E}+02$ \\
$7 \%$ & $10 \%$ & 0.05 & 0.500 & -0.450 & 0.550 & $1.00 \mathrm{E}+03$ \\
\hline
\end{tabular}

Comparisons that are significantly different $(\mathrm{p}<0.05)$ are highlighted in grey.

Table 7. Tukey's test for main effects of B-lac concentrations.

\begin{tabular}{ccccrcc}
\hline \multicolumn{2}{c}{ Levels } & Diff. mean & mean crit. & lower & upper & p-value \\
Group 1 & Group 2 & & & & & \\
\hline $0 \%$ & $1 \%$ & 0.08 & 0.500 & -0.424 & 0.577 & 0.998 \\
$0 \%$ & $3 \%$ & 0.24 & 0.500 & -0.259 & 0.742 & 0.718 \\
$0 \%$ & $5 \%$ & 0.67 & 0.500 & 0.173 & 1.174 & 0.002 \\
$0 \%$ & $7 \%$ & 0.73 & 0.500 & 0.228 & 1.229 & 0.001 \\
$0 \%$ & $10 \%$ & 0.80 & 0.500 & 0.303 & 1.304 & 0.000 \\
$1 \%$ & $3 \%$ & 0.17 & 0.500 & -0.335 & 0.665 & 0.927 \\
$1 \%$ & $5 \%$ & 0.60 & 0.500 & 0.096 & 1.097 & 0.010 \\
$1 \%$ & $7 \%$ & 0.65 & 0.500 & 0.151 & 1.152 & 0.004 \\
$1 \%$ & $10 \%$ & 0.73 & 0.500 & 0.226 & 1.227 & 0.001 \\
$3 \%$ & $5 \%$ & 0.43 & 0.500 & -0.069 & 0.932 & 0.130 \\
$3 \%$ & $7 \%$ & 0.49 & 0.500 & -0.014 & 0.987 & 0.061 \\
$3 \%$ & $10 \%$ & 0.56 & 0.500 & 0.061 & 1.062 & 0.019 \\
$5 \%$ & $7 \%$ & 0.05 & 0.500 & -0.445 & 0.555 & 1.000 \\
$5 \%$ & $10 \%$ & 0.13 & 0.500 & -0.370 & 0.630 & 0.973 \\
$7 \%$ & $10 \%$ & 0.07 & 0.500 & -0.425 & 0.575 & 0.998 \\
\hline
\end{tabular}

Comparisons that are significantly different $(\mathrm{p}<0.05)$ are highlighted in grey.

\footnotetext{
${ }^{1}$ Department of Environmental Engineering / La Molina National Agrarian University. Av. La Molina s/n, Lima 12 / Perú. ORCID: 0000-0002-1075-8419. jepoalva@gmail.com.

${ }^{2}$ Department of Environmental Engineering / La Molina National Agrarian University. Av. La Molina s/n, Lima 12 / Perú. g.canoarcos@gmail.com.

${ }^{3}$ Academic Department of Biology / La Molina National Agrarian University. Av. La Molina s/n, Lima 12 / Perú. jjm@lamolina.edu.pe.

4 Science Faculty / La Molina National Agrarian University. Av. La Molina s/n, Lima 12 / Perú. lquipuzco@lamolina.edu.pe.
} 